\title{
School Administration and Role in Promoting Intellectual Security among Students
}

\author{
Zina Hamody Hussain \\ Faculty of education for Pure Science- IBN Alhaitham- Baghdad University
}

\begin{abstract}
This message is aimed to identify abstract on this extent of intellectual insecurity among middle school and junior high students in the directorate General for education Baghdad / first Karkh, where the research community of middle managers and junior high school of the general Directorate for educational Baghdad/ Karkh the first academic year (2015 - 2016$)$ the research sample consisted of 95 middle and junior high school principals were research sample randomly selected and to collect information from the sample researcherAstana adopted to collect information, data has been using the proportion of spending, and the weighted analysis, Wight semen, and standard deviation. The result revealed that the degree of the role of school administration in promoting intellectual insecurity among middle students and junior high in stage in all it was the year of arithmetic-answer sample for the study tool whole medium as the average was (3.03) and moderately exercise. It is the most important recommendations reached by the researcher are : 1) The need to develop an targeted strategy and intellectual security for young people and citizens. 2) Make a good teaching so that security prevails establish a relationship with the school administration and the board gore and confidence in the school. 3) Include courses some topics related to intellectual security, and look at the development of continuously developing to combat various forms of intellectual deviation.
\end{abstract}

\section{Research Problem}

The middle school and junior high of more levels of education that must be highlighted as a critical stage in human life, where individual is affected by many factors which require enclosed by means of prevention, care and guidance. In this sense we must stand on the subject in the attempt to develop a true vision of the scientific approach to the role of education in fostering intellectual security of the students which is armor to national security in General, and through several axes to reach conclusions and recommendations achieve this security. The importance of research: intellectual security is of great importance to guarantee the security and stability of the society, the intellectual security community members automatically achieves security in all its purposes if tightened disclosure, which might be called comprehensive security '. (Al-Haidar, 2011,366 ) and intellectual security issue is not a new issue but it has emerged because of the emergence of modern media and the Internet took a backseat to community issues.

The significance of the role of research on school protection thought arising from perverse ideas, especially at this critical stage of the age which is shaped by human thinking and crystallize, so create intellectual security school students and fortifying them against whatever offends the minds and accommodate extraneous thoughts and developments With all of the distractions and extremism, which sometimes leads to violence and terrorism and thus destabilize society.

\section{Aim of Research}

Learn how intellectual security among students in junior high and middle school in the Directorate General for raising Baghdad/Karkh. Limit search: current research is limited to middle schools and junior managers in the Directorate General for raising first-year flood (2015/2016). Define the terms: he knew the school administration:

1) Al-hoqail, 2002): 'every effort in planning, organization, coordination and direction for all educational work happens inside the school, for the development and advancement of education '. (Al-hoqail, 2002, 35) known (Hussein, 2005): ' the process of planning, coordinating and directing all the action occurs within a pedagogical education or school for development and advancement of education, or an activity checks behind educational purposes in accordance with selected models and selected by the school administration. (Hussein, 2005, 19).

2) The researcher know school administration procedural: a set of educational goals that are achieved by educational leadership committed to the responsibility of overseeing the school, administratively and technically, educationally, as bearing upon the student conservation and protection Secretariat, strengthen ideological security, public policy and the educational philosophy developed by the Ministry.

Intellectual security defined:

1) (Alharbi , 2011): ' to provide immunity early intellectual for the individual to access the moderation in dealing with religious, social and political matters. (Alharbi , 2011, 23).

2) knows (Fahjan, 2012): ' safety and prevention thought principles and beliefs and constants of the students and keep them from negative influences and perverted ideas all through the school management role in providing meaningful programs and activities contribute to the intellectual and provide security. Students with proper thinking '. (Fahjan, 2012, 2) procedural defined intellectual security researcher: total events and activities by the school administration to fortify the minds of the students with sound ideas on religion, politics and culture in the face of good ideas that are inconsistent with the right thought in the Iraqi society, with a view to Set up and configure the proper character actors. 


\section{International Journal of Science and Research (IJSR)}

ISSN (Online): 2319-7064

Index Copernicus Value (2016): 79.57 | Impact Factor (2015): 6.391

\section{Theoretical Background and Previous Studies}

Study of Sulaiman (2006) school departments ' role in promoting students ' intellectual security. The purpose of this study is to explain the role of school in fostering intellectual security departments for students. Use descriptive, with sample (400) Manager and agent in three stages, and the researcher adopted a questionnaire to collect the necessary data. Below are highlights of the findings of the study:

1) High school administrators felt that the need to enhance security of great students.

2) That school administrations have knowledge of methods and procedures in promoting students ' intellectual security.

3) That school administrations in stages that play a major role to activate the role of the teacher in promoting students ' intellectual security.

4) That school administrations in three stages using multiple teaching methods to enhance the ideological security in the school environment with the overall high standard except the coordination with the competent authorities to deal with hardship cases.

And the study's recommendations:

1) Identify the trends of intellectual students early.

2) School departments and different programs supporting overall security and ideological security in particular.

3) Effective opening between departments and educational institutions, plans and common perceptions of intellectual security enhancement. Senary study (2008), entitled ' the role of school management in establishing societal values of intellectual deviation ' the purpose of this study is to explain the role of school management in consolidating community values to prevent intellectual deviation. The researcher used descriptive survey. Have the sample of the study consisted of (426) from educational leaders (director, agent, ekonomist) and teachers, the researcher used the questionnaire as a tool for data collection.

One of the most important results of the study:

1) To what blindingly obvious intellectual deviation study addressed.

2) The study agreement on the most prominent intellectual deviation reasons: lack of cooperation between family and school and family disintegration in all forms, bad company, social disintegration and lack of responsibility towards the community, and all means of notification.

3) Study consensus to apply community values and work on it instilled in high school, the most important of these values, belief in allah and belonging to the islamic community, identity, and arabic culture, innovation, creativity, action, and dialogue, moderation and tolerance.

4) Individual differences are statistically significant at a level $(0.05)$ between the study views depending on the job, and for educational leaders.

The researcher recommended recommendations:
1) Strengthening the role of the parent in continuous monitoring throughout the year by the school administration.

2) A greater role for student leader in school not only turn on the recording of offences within the school but also to identify the family circumstances of the student.

3) Support national reform efforts to achieve social balance.

4) The need for different media in enlightening the students intellectual deviation problem.

\section{Characteristics of successful school management:}

The school administration through its processes and activities with the administrative work of the Supreme goal of society and is raising a healthy balanced breeding society, this requires that the school administration with specific properties. Requires Department of transportation to be purposeful, and her positive leadership role in the areas of employment and guidance. (Solomon, 1999, 380). It also requires you to be away from social tyranny and authoritarianism, responsive to advice, aware of the public good, and good humanitarian treatment of others and help them reach the right solutions to them. (Hussain, 2004, 31)

\section{Causes of intellectual deviation:}

There are several reasons lead to intellectual deviation from the gap between religious leaders and youth and inadequate educational and social media and youth on devices to play their role, and the emptiness of youth and lack their own programs running their free time to help them, And develop in them Islamic values and sense of loyalty and belonging to society, weak domestic and exactly a bug in communication between parents and children, as well as the frustrations experienced by youth as a result of the security conditions and the difficult social and economic life of the community and the cultural year after 2003 in Iraq, sought Some States to weaken Islamic States and sow division among them. (AlOtaibi, 2009, 49 5)

\section{The role of school management in promoting ideological security:}

School administration can play several roles in promoting ideological security among students through a set of points in the questionnaire design adopted for this research

First: the role of school management: the principal's role is determined to strengthen ideological security $\mathrm{p}$ The most important things:

1) Cooperation with the educational guide and facilitate his potential to apply guidance and counseling programs.

2) Note and follow the general behavioral phenomena and collaborate with faculty and educational leader in evaluating behaviors.

3) Climate and valid learning environment helps spread an atmosphere of tranquility and security.

4) Interest in school activities such as: school radio and school theatre. Etc.

5) Encourage teachers to students ' talent and providing potential for growth.

6) Leadership team orientation and educational counseling in school and providing opportunities for team members to play their respective roles. (helen, 2006, 165) 


\section{International Journal of Science and Research (IJSR) \\ ISSN (Online): 2319-7064}

Index Copernicus Value (2016): 79.57 | Impact Factor (2015): 6.391

Second: the role of the faculty member:

teacher has a considerable burden in promoting ideological security have requested, it is the leader, so that its role in promoting ideological security of students is:

1) Emphasize good example for request disposition and behavior, and harmony with the values of Islam and Guan Wayne community.

2) Establish the principle of dialogue and listening to others in order to get to the truth and help students to think in a proper manner.

3) Interest in social education.

4) Attention to teach proper standards of behavior.

5) Encourage cooperation between parents and various social institutions.

6) Guide students to ways to find the right information and encourage them to do so.

7) The understanding of the nature of their minds to easily contact them. (Hussain, 18-20, 2004).

Third: the role of school activities: programs by students within the school or outside according to their preferences and aptitudes and abilities as potential available to them that are related to the curriculum, either directly or indirectly, and under the supervision of the school in order to achieve the objectives of the operation. So the role of educational activities in the following:

1) To instill principles and values of Islam and their translation into practice and deepened in the minds of students.

2) Support learning resources at school research and books and studies that enhance intellectual security.

3) Protection from misleading and perverted thoughts.

4) Communicate with the local community and hosting dignitaries and officials and cooperating with them in the dissemination of ideas.

5) Educational pamphlets promote correct behavior and warns of drift and risks.

6) Attention to student councils. (Al-kharji, 2010, 44).

Fourth: the role of educational leader:

Highlights the role of educational leader in promoting ideological security through the following points:

1) Highlight the value of individual responsibility in students ' intellectual security permanently in the school environment and in society.

2) Promote the correct security behavior among students and motivate them to secure their country and its riches and possessions.

3) Diagnosis and disorderly calendar security among students.

4) Refine terms and correct misconceptions among students.

5) Stay away from intolerance and vandalism in the school community, and develop effective preventive programs.

6) Encourage parents to support and continue the friendship of their children in school and out.

7) To provide advice and guidance to students.

8) To listen to students and discuss with them the right way, and gives them the opportunity to express their opinions and attitudes.

9) To employ different technical means such as the internet, multimedia and data transmission property like bluetooth to enhance students ' intellectual security. (helen, 2006, $165)$.

\section{Research Methodology}

Descriptive analytical researcher adopted to achieve the objective of the research is among the most common curricula in educational research, and depends on the style of field study beyond the description of the phenomenon research subject to analysis and interpretation.

Second: Community research: current research community consists of middle and secondary school principals of the General Directorate of education first-lieutenant 2015/2016 school year. The data have been obtained and the setup information and figures relating to the research community through the Planning Department statistics in Al Karkh Directorate first breeding of Baghdad under book facilitate mission extension (1)

Table 1: Research community according gender variable

\begin{tabular}{|c|c|c|}
\hline Percentage & Frequency & Gender \\
\hline 58,6 & 112 & Male \\
\hline 41,3 & 79 & Female \\
\hline 100 & 191 & Total \\
\hline
\end{tabular}

Third research sample: the sample consisted of (95) of secondary school principals of the general directorate of education first-lieutenant for the academic year 2015-2016 researcher has chosen a sample search simple random sample is $50 \%$ of the research community, distributed (95) questionnaire and secondary schools principals, you roll back (92), and after reviewing the questionnaires show that there are (7) extremely unfit for analysis, and this became the study sample consisting of (85) Director and Director, table 3 shows the distribution of respondents according to gender variables and educational experience.

Table 2: Sample search by gender variable

\begin{tabular}{|c|c|c|}
\hline Percentage & Frequency & Gender \\
\hline 57.6 & 49 & Male \\
\hline 42.4 & 36 & Female \\
\hline 100 & 85 & Total \\
\hline
\end{tabular}

Fourth: search tool: the researcher adopted a questionnaire for collecting the information needed to identify the role of school management in promoting ideological security among students by following the steps outlined below: a reconnaissance survey: researcher questions open to intermediate managers and sample. and it also open to those , who have nothing to do with this topic within the General Directorate of education first lieutenant and asked them which they consider paragraphs statement suitable for every area of research, and add any idea or comment related to the topic. B access to literature on the subject of books and theses and doctoral research and thesis related question. The above steps, the questionnaire was prepared by the initial version and included (58) extension (1) distributed among four areas (the role of school management, teachers ' role, the role of school activities, the role of educational leader) in promoting ideological security among students as shown in table (3). 


\section{International Journal of Science and Research (IJSR) ISSN (Online): 2319-7064}

Index Copernicus Value (2016): 79.57 | Impact Factor (2015): 6.391

Table 3: Preliminary questionnaire

\begin{tabular}{|c|c|c|}
\hline Paragraph no. & Type & No. \\
\hline 15 & school administration & 1 \\
\hline 14 & teachers & 2 \\
\hline 14 & School activities & 3 \\
\hline 15 & Educational guide & 4 \\
\hline 58 & total \\
\hline
\end{tabular}

\section{Fifth: honestly of the tool}

Fifth: honestly the tool: the honesty of important characteristics that need attention when you perform a search and search tool being honest when you measure what you suppose to measure it because the genuine test that test that can measure the attribute or trait that put for her. (Marwan, 2000, 43) to learn honesty phenotype search tool; it has been viewed as the initial group of arbitrators and their number (12), (2), with specialization in the field of research, professors adoption agreement rate $(80 \%)$ and above, and asked them to identify appropriate paragraphs in the Palace. Research and objective clarity and integrity of the vertebrae, and to propose any adjustments or add the paragraphs they deem necessary, and unnecessary paragraphs deleted,numbered paragraphs before refereeing (58), then the researcher make adjustments, then the researcher proposed modifications of Arbitrators, finalized (56), as shown in the table (4).
Table 4: The finalized questionnaire

\begin{tabular}{|c|c|c|}
\hline Paragraph no. & type & No. \\
\hline 14 & School Administration & 1 \\
\hline 14 & Teachers & 2 \\
\hline 14 & School Activities & 3 \\
\hline 14 & Educational Guide & 4 \\
\hline 56 & Total \\
\hline
\end{tabular}

With the modify and delete some paragraphs as shown in the table above as follows: in the role of school management paragraph 12 is deleted so that paragraphs (14) paragraph, amend paragraph (14) paragraphs remained as is, either the role of teachers had been amended paragraphs $(5,6)$, paras. To another as they are, bringing the number of paragraphs (14), and in school activities was amended paragraph (6) and the other paragraphs remain as they are, so have the number of paragraphs (14), in the area of educational guide was amended paragraphs (9) and to delete paragraph (12) to (14) and the other paragraphs remain as What are.

\section{Statistical methods:}

Agreement, Center-weighted, and weight percentage, and standard deviation.

\section{Presentation and discussion of results:}

to achieve the goal of identifying applied research for identifying the extent of intellectual security among students in junior high and middle school in the General Directorate of education first, Baghdad/Karkh extracted arithmetic means and standard deviations of the study sample answers Research, table 5 shows that

Table 5: Arithmetic averages and standard deviations of the sample responses on descending study tool

\begin{tabular}{|c|c|c|c|c|c|c|}
\hline Percentage weight & The degree of practice & Standard deviation & mean & type & No. & rank \\
\hline 82,8 & high & 0,77 & 4,14 & school administration & 1 & 1 \\
\hline 59,6 & medium & 0,65 & 2,98 & teachers & 2 & 2 \\
\hline 51 & medium & 0,27 & 2,55 & School activities & 5 & 3 \\
\hline 49,4 & medium & 0,35 & 2,47 & Educational guide & 4 & 4 \\
\hline \multicolumn{2}{|c|}{ medium } & 0,26 & 3,03 & \multicolumn{3}{|c|}{ total } \\
\hline
\end{tabular}

As shown in table (5) the degree of school management role in strengthening security in middle school students and intellectual Prep in general medium because the arithmetic mean of the sample answers about the whole study tool reached $(3,3)$ and medium practice degree, as results showed that arithmetic respondents ranged from Pat $(2,98$, $4,14)$ was on top of the area ' school management ' arithmetic mean $(4,14)$ and the degree of exercise are high, in second place came the field ' teachers ' arithmetic average
$(98,2)$ medium degree exercise and third place came the area ' school activities ' arithmetic mean $(2,55)$ degree, in fourth place came the area ' educational ' Guide to arithmetic $(2,47)$ and the degree of exercise.

It was extracted arithmetic and standard deviations of respondents answer from paragraphs each study individually, tables (6) and (7) illustrate that.

Table 6: Mathematical averages and standard deviations of the sample answers for school administration paragraphs in descending order

\begin{tabular}{|c|c|c|c|c|c|c|}
\hline $\begin{array}{l}\text { Percentage } \\
\text { weight }\end{array}$ & $\begin{array}{l}\text { The degree } \\
\text { of practice }\end{array}$ & $\begin{array}{l}\text { Standard } \\
\text { deviation }\end{array}$ & mean & type & No. & rank \\
\hline 94,8 & high & $\mathbf{0 , 6 9}$ & $\mathbf{4 , 7 4}$ & Help resolve personality conflicts among students & 3 & 1 \\
\hline 94,4 & high & $\mathbf{0 , 7 0}$ & 4,72 & The School Board recognizes & 1 & 2 \\
\hline 93,6 & high & $\mathbf{0 , 9 0}$ & 4,68 & $\begin{array}{l}\text { Leads work on the principle of cooperation on land WA distributes } \\
\text { opportunities to exercise extracurricular activities among students }\end{array}$ & 7 & 3 \\
\hline 93,2 & high & $\mathbf{0 , 9 6}$ & 4,66 & . Notice the General behavioural phenomena among students. & 4 & 4 \\
\hline 93.0 & high & $\mathbf{0 , 9 8}$ & 4,65 & the needs of students in their learning. & 5 & 5 \\
\hline 93,0 & high & $\mathbf{0 , 9 5}$ & 4,65 & A climate of love and cooperation among students. & 9 & 6 \\
\hline 92,8 & high & $\mathbf{1 , 0 1}$ & 4,64 & Stay away from everything raises excellence among students & 6 & 7 \\
\hline 92,8 & high & $\mathbf{1 , 0 3}$ & 4.64 & .. Coordinate efforts among the educational community. & 8 & 8 \\
\hline 92,4 & high & $\mathbf{0 , 9 9}$ & 4,62 & Instill a love school management teamwork among students & 2 & 9 \\
\hline
\end{tabular}

\section{Volume 6 Issue 12, December 2017}




\section{International Journal of Science and Research (IJSR) \\ ISSN (Online): 2319-7064}

Index Copernicus Value (2016): 79.57 | Impact Factor (2015): 6.391

\begin{tabular}{|c|c|c|c|c|c|c|}
\hline $\begin{array}{c}\text { Percentage } \\
\text { weight }\end{array}$ & $\begin{array}{c}\text { The degree } \\
\text { of practice }\end{array}$ & $\begin{array}{c}\text { Standard } \\
\text { deviation }\end{array}$ & mean & type & No. & rank \\
\hline $\mathbf{6 6 , 6}$ & medium & $\mathbf{1 , 0 8}$ & $\mathbf{3 , 3 3}$ & Urges parents and children experience recurrent needs and work to their & $\mathbf{1 2}$ & $\mathbf{1 0}$ \\
\hline $\mathbf{6 4 , 0}$ & medium & $\mathbf{1 , 2 1}$ & $\mathbf{3 , 2 0}$ & . Organize periodic meetings open with students to discuss public affairs. & $\mathbf{1 3}$ & $\mathbf{1 1}$ \\
\hline $\mathbf{6 3 , 2}$ & medium & $\mathbf{1 , 2 2}$ & $\mathbf{3 , 1 6}$ & Development of leadership attitudes among students. & $\mathbf{1 0}$ & $\mathbf{1 2}$ \\
\hline $\mathbf{6 3 , 2}$ & medium & $\mathbf{1 , 2 1}$ & $\mathbf{3 , 1 6}$ & Family urges to follow their children's behavior inside and outside the & $\mathbf{1 1}$ & $\mathbf{1 2}$ \\
\hline $\mathbf{6 1 , 8}$ & medium & $\mathbf{1 , 2 6}$ & $\mathbf{3 , 0 9}$ & . Invite parents to experience more serious lectures age level of the student. & $\mathbf{1 4}$ & $\mathbf{1 4}$ \\
\hline $\mathbf{8 2 , 8}$ & high & $\mathbf{0 , 7 7}$ & $\mathbf{4 , 1 4}$ & \multicolumn{2}{|c|}{ School administration type as a whole } & \\
\hline
\end{tabular}

table shows (6) as follows:

1. There are nine paragraphs got high degree; ranging from arithmetic to respondents answer about these passages between $(4,62,4,74)$ was highest for paragraph (3) which reads ' help resolve personality conflicts among students. ', second paragraph (came 1) and read ' the school administration is aware of their students need to learn. ' arithmetic mean $(4,72)$, third paragraph (7) came and read ' leads work on the principle of cooperation in righteousness and piety. ' Arithmetic mean $(4,68)$, and was lowest for paragraph (4) ' distributes opportunities to exercise extracurricular activities among students of Justice.
2.There are five paragraphs got moderate exercise arithmetic answers ranged from respondents on these paragraphs $(3,9$, 3 , 33) was highest for paragraph 12, which read ' urges parents to experience recurrent and sons and their work satisfied. ' And ranked second only to paragraph (13) came and read ' organizes periodic meetings open with students to discuss public affairs. ' arithmetic mean $(3,12)$, and third paragraphs came $(10,11)$ paragraph $(10)$ ' development of leadership students ' attitudes, while paragraph (11) Read ' urges families to follow their children's behavior inside and outside the home ' arithmetic mean $(3,16)$, and was lowest for paragraph (14) reading ' invite parents to experience more serious lectures age level of the student.

Table 7: Arithmetic means and standard deviations of respondents answer from paragraphs area teachers in descending order.

\begin{tabular}{|c|c|c|c|c|c|c|}
\hline $\begin{array}{l}\text { Percentage } \\
\text { weight }\end{array}$ & $\begin{array}{l}\text { The degree } \\
\text { of practice }\end{array}$ & $\begin{array}{l}\text { Standard } \\
\text { deviation }\end{array}$ & mean & type & No. & rank \\
\hline 68,7 & medium & 1,07 & 3,44 & Right-thinking workshop development among & 11 & 1 \\
\hline 68,0 & medium & 0,97 & 3,40 & $\begin{array}{l}\text { Directs students towards research methods } \\
\text { for the correct information }\end{array}$ & 8 & 2 \\
\hline 67,8 & medium & 1,17 & 3,39 & Promotes the importance of security and save interest & 10 & 3 \\
\hline 67,5 & medium & 1,06 & 3,38 & Interested in instilling behavioural norms and values among students. & 9 & 4 \\
\hline 65,9 & medium & 1,03 & 3,29 & Helps to solve problems of students. & 13 & 5 \\
\hline 65,9 & medium & 1,15 & 3,29 & Teaches students the boundaries of personal freedom & 14 & 6 \\
\hline 64,0 & medium & 1,17 & 3,20 & $\begin{array}{l}\text { Understanding the nature of student thinking to make it easier to communicate } \\
\text { with them. }\end{array}$ & 7 & 7 \\
\hline 62,6 & medium & 1,18 & 3,13 & $\begin{array}{l}\text { Stay away from ideas which develop a sense of loathing and hatred towards } \\
\text { society. }\end{array}$ & 6 & 8 \\
\hline 56,5 & medium & 1,32 & 2,82 & Demonstrates security breach risks on the individual and society. & 12 & 9 \\
\hline 52,5 & medium & 0,76 & 2,62 & $\begin{array}{l}\text { Establishes the principle of teachers a meaningful dialogue and listen to } \\
\text { everyone's opinion. }\end{array}$ & 2 & 10 \\
\hline 52,5 & medium & 0,76 & 2,62 & Students Guide students toward choosing companionship. & 5 & 10 \\
\hline 50,8 & medium & 084 & 2,54 & Educate students to confront extremist ideas and beliefs. & 4 & 12 \\
\hline 49,6 & medium & 0,87 & 2,48 & Instills the love of country teachers students. & 3 & 13 \\
\hline 42,6 & low & 0,88 & 2,13 & Teachers help students grasp concepts and ideas that relate to life. & 1 & 14 \\
\hline 59,6 & & 0,65 & 2,98 & Teachers type as a whole & & \\
\hline
\end{tabular}

Appears from the table (7) to all paragraphs of area teachers got a medium degree exercise except paragraph (1) which reads ' teachers helps students grasp the concepts and ideas that pertain to life.' they got exercise low arithmetic mean $(2,13)$, ranging from arithmetic for answers. Sample unit from the rest of the field between paragraphs (2.48) and (3, 44) medium score, the top paragraph (11) and read ' right- thinking workshop development of the students ', second paragraph (8) came and read ' students towards research methods for correct information. ' Arithmetic average (3, $40)$, in third place came the paragraph number (10) and read ' develop important security and save the national interest .

Table 8: Arithmetic means and standard deviations of the sample answers about school activities paragraphs in descending order

\begin{tabular}{|c|c|c|c|c|c|c|}
\hline $\begin{array}{c}\text { Percentage } \\
\text { weight }\end{array}$ & $\begin{array}{c}\text { The degree } \\
\text { of practice }\end{array}$ & $\begin{array}{c}\text { Standard } \\
\text { deviation }\end{array}$ & mean & type & No. & rank \\
\hline 42,4 & low & 0,98 & 2,12 & Educational exhibitions that emphasize the importance of security. & 9 & 1 \\
\hline 42,1 & low & 0,96 & 2,11 & School activities on scientific bases & 4 & 2 \\
\hline 41,6 & low & 0,97 & 2,08 & $\begin{array}{c}\text {.. Management is dedicated to school activities and a national security } \\
\text { awareness }\end{array}$ & 2 \\
\hline 41,4 & low & 0,97 & 2,07 & renew school activities to be more interesting & 5 & 4 \\
\hline 40,9 & low & 0,95 & 2,05 & Renewal of school activity to be more appropriate & 13 & 5 \\
\hline
\end{tabular}

\section{Volume 6 Issue 12, December 2017}




\section{International Journal of Science and Research (IJSR) \\ ISSN (Online): 2319-7064}

Index Copernicus Value (2016): 79.57 | Impact Factor (2015): 6.391

\begin{tabular}{|c|c|c|c|c|c|c|}
\hline $\begin{array}{c}\text { Percentage } \\
\text { weight }\end{array}$ & $\begin{array}{c}\text { The degree } \\
\text { of practice }\end{array}$ & $\begin{array}{c}\text { Standard } \\
\text { deviation }\end{array}$ & mean & type & No. & rank \\
\hline 40,2 & low & 0,96 & 2,01 & . Enhances intellectual security programs contents of school activities. & 6 & 6 \\
\hline 39,5 & low & 0,94 & 1,98 & Engages students with intellectual security articles in school activities. & 11 & 7 \\
\hline 38,8 & low & 0,97 & 1,94 & . Instill a sense of maintaining public libraries and school & 8 & 8 \\
\hline 37,9 & low & 0,94 & 1,89 & Barricaded school activities students minds distractions.. & 7 & 9 \\
\hline 37,6 & low & 0,92 & 1,88 & Illustrate the importance of school activities for students. & 1 & 10 \\
\hline 37,6 & low & 0,94 & 1,88 & $\begin{array}{c}\text { Include the contents of activities to discuss scientific matters that hide } \\
\text { many youth and ignorance leads to intellectual deviation. }\end{array}$ & 12 & 10 \\
\hline 37,4 & low & 0,92 & 1,87 & Employ students opinions on school activities. & 3 & 12 \\
\hline 36,9 & low & 0,91 & 1,85 & $\begin{array}{c}\text { Hosting specialist for dialogue and discussion with students about } \\
\text { intellectual security. }\end{array}$ & 10 & 13 \\
\hline 36,5 & low & 0,92 & 1,82 & Lack of funds for school activities & 14 & 14 \\
\hline 39,4 & low & 0,84 & 1,97 & School activity as a whole & \\
\hline
\end{tabular}

Appears from the table (8) to all paragraphs of the school activities obtained a low exercise arithmetic answers ranged from the sample domain between paragraphs $(1,82)$ and $(2$, 12), top paragraph 9 which read ' educational exhibitions that emphasize the importance of security. ', Second paragraph (4) came and read ' school activities is scientifically. ' arithmetic mean $(2,11)$, and third place came

arithmetic means and standard deviations of the sample answers about educational guide field paragraphs in descending order. the paragraph number (2) which reads ' dedicated management school activities to achieve national security awareness ' arithmetic mean $(2,8)$, came in last paragraph (14) Reading ' lack of financial allocations to school activity.

Table 9:

\begin{tabular}{|c|c|c|c|c|c|c|}
\hline 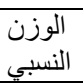 & 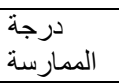 & 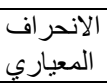 & الحتوسط & الفقرة & الرقم & الرت \\
\hline 55,3 & medium & 0,53 & 2,76 & strengthen programms aimed at raising their security. & 10 & 1 \\
\hline 55,1 & medium & 0,53 & 2,75 & strengthen programs aimed at raising their security . & 11 & 2 \\
\hline 54,6 & medium & 0,54 & 2,73 & $\begin{array}{l}\text {. Educational guide directs students to how to draw positive thoughts of study } \\
\text { material }\end{array}$ & 1 & 3 \\
\hline 53,4 & medium & 0,56 & 2,67 & Behavioral treatment of delinquent students directs gently & 9 & 4 \\
\hline 52,0 & medium & 0,66 & 2,60 & Culture spirit of team work and participate in the decisions making & 14 & 5 \\
\hline 50,1 & medium & 0,70 & 2,51 & meeting with the students with negative ideas to develop appropriate solutions & 8 & 6 \\
\hline 49,9 & medium & 0,70 & 2,29 & Demonstrates behaviors risk to themselves and society & 12 & 7 \\
\hline 48,5 & medium & 0,78 & 2,42 & Friendly relations with students in order to know their problems & 6 & 8 \\
\hline 48,2 & medium & 0,76 & 2,41 & $\begin{array}{l}\text { Discuss with parents about the problems encountered by intellectual orientation. } \\
\text { Urging them to acquire educational culture }\end{array}$ & 2 & 9 \\
\hline 48,0 & medium & 0,74 & 2,40 & $\begin{array}{l}\text { directed security dimensions the importance of student disclosure about their } \\
\text { problems. }\end{array}$ & 3 & 10 \\
\hline 47,8 & medium & 0,71 & 2,39 & Cares at whose economic conditions for students and provide them with assistance. & 5 & 11 \\
\hline 47,5 & medium & 0,79 & 2.38 & Know the problems of the students and put appropriate solution for it . & 7 & 12 \\
\hline 42,1 & low & 0,85 & 2,11 & . Investment guide in strengthening the relationship between the school and home. & 13 & 13 \\
\hline 40,2 & low & 0,82 & 2,01 & Works to relieve the concerns of the students. & 4 & 14 \\
\hline 49,4 & medium & 0,35 & 2,47 & Educational guide type & & \\
\hline
\end{tabular}

The table shows (9):

1. There are twelve paragraph got moderate exercise ranging arithmetic for respondents answers about these passages between $(2,38,2,76)$ was highest for paragraph (10) and read ' develop good thinking habits and problem solving among students. ', ranked Paragraph (11) came second and reading ' fosters programs that aims to raise the intellectual security. ' Arithmetic mean $(2,75)$, in third place came the paragraph (1) which reads ' educational guide directs students to how to draw positive thoughts of subjects ' arithmetic mean (2.73), was the lowest of paragraph (7) and read ' cares at whose economic conditions for students and assistance Them. '.

2. There are two obtained a low exercise; ranging from arithmetic to respondents answer about these passages between $(2,1)$ and $(2,11)$ was highest for paragraph $(13)$ and read ' investment guide in strengthening the relationship between the school and home. ', and was the lowest for paragraph (4) and read ' works Easing the concerns of the students.

In order to answer the following question: is there a statistically significant differences at the level of the indication $(\alpha \leq 0.05)$ in the role of school management in promoting students ' intellectual security depending on the variable sex? To answer that question, a test was applied (Independent Samples T-Test) on fields of study, and whole tool depending on the sex variable, table 10 shows that the table (10) the results of the test application (Independent Samples T-Test) on fields of study, and whole tool depending on the variable gender. 
International Journal of Science and Research (IJSR)

ISSN (Online): 2319-7064

Index Copernicus Value (2016): 79.57 | Impact Factor (2015): 6.391

\begin{tabular}{|c|c|c|c|c|c|c|}
\hline \multirow{2}{*}{ Statistical significance } & \multirow{2}{*}{$\mathrm{T}$} & \multicolumn{2}{|c|}{ female } & \multicolumn{2}{|c|}{ male } & \multirow{2}{*}{ type } \\
\cline { 3 - 7 } & & Standard deviation & mean & Standard deviation & mean & \\
\hline 0,36 & 0,93 & 0,67 & 4,29 & 0,80 & 4,10 & school administration \\
\hline 0,00 & 3,43 & 0,31 & 2,53 & 0,67 & 3,10 & teachers \\
\hline 0,00 & 4,33 & 0,26 & 2,68 & 0,84 & 1,79 & School activities \\
\hline 0,36 & 0,91 & 0,42 & 2,54 & 0,33 & 2,45 & Educational guide \\
\hline 0,07 & 1,83 & 0,21 & 3,01 & 0,27 & 2,86 & Instrument as a whole \\
\hline
\end{tabular}

Show table (10):

1) Lack of statistically significant differences at the level of the indication $(\alpha \leq 0.05)$ in the role of school management in promoting ideological security among students (school administration, teachers, school activities) depending on the variable sex, with all values (T) is a statistical function.

2) Statistically significant differences at the level of the indication $(\alpha \leq 0.05)$ in the role of school management in promoting ideological security among students (educational guide) depending on the variable gender, arithmetic shows that these differences were in favor of females; Arithmetic mean of female managers answer is higher than that for male managers.

\section{Conclusions}

1) Education is an important reason that promote ideological security in emerging through various components.

2) The important role that falls to the educational leader in promoting students ' intellectual security through advice and guidance.

3) The teacher assumes the bulk of intellectual security among students by bringing up valid islamic upbringing students, helping them understand concepts and ideas away from deviant and extremist ideas and represent role models, as well as establish the principle of meaningful dialogue, listening and respect. Others down to the right, and to encourage cooperation with the family.

4) The scientific materials play an important role and fundamental approaches to achieve ideological security, which seeks to establish islamic curriculum based on integrity and moderation.

5) The student may be subject to intellectual deviation due to poor educational environment climate.

\section{Recommendations}

1) The need to develop an integrated strategy defined to deal with the problem of intellectual extremism and intellectual security protection for young people and citizens.

2) Allow the educational guide for extension functions and not with matters of administration.

3) Establishing a good relationship with the school administration and teaching staff so that security reigns and trust in the school.

4) Develop programs to detect students who hold ideas contrary ideological security.

5) The need for educational institutions in coordination with civil society institutions to raise such issues and develop plans and programs for the prevention of delinquency and the development and processing.
6) Students are urged to report anyone carrying a deviant thought either the teacher or educational leader, and involving the school principal.

7) Some courses include topics relevant to achieve ideological security, given the continuous development to combat various forms of intellectual deviation.

\section{Proposals}

The researcher proposes to conduct studies on the following: 1. the role of school management in planning curriculum for middle school and junior high. 2. conceiving proposal for activating the role of school management in intellectual security among students.

\section{References}

[1] Al Harbi, Sultan bin Mujahid bin Sayer, The role of school administration in achieving intellectual security among high school students in Taif from the point of view of the principals and agents of these schools, unpublished Master Thesis, Faculty of Education, Umm Al-Qura University, Makkah Al-Mukarramah, 2011.

[2] Hussain, Salameh Abdel-Azim, Recent Trends in Effective School Management, 1, Dar Al-Fikr Publishing, Jordan, Amman, 2004.

[3] Alhaqeel, Salama Abdul Azim, Abdul Rahman, School Administration And the mobilization of human forces in the Kingdom of Saudi Arabia, Dar Alam Books for publication and distribution, 2002.

[4] Al Haidar Abdul Rahman, ideological security in the face of intellectual influences, unpublished $\mathrm{PhD}$ thesis, submitted in police Sciences, Faculty of Islamic studies at the Police Academy, Arabic Republic of Egypt.

[5] Al Kharje, Abdul Wahid Abdul Aziz, student leader's effectiveness in promoting ideological security of secondary school students, unpublished thesis, Riyadh: Naif for Security Sciences.

[6] Fahjan, Naser Khalil, the role of school management in promoting ideological security at secondary students in Gaza and ways to activate, unpublished thesis, school of education, Islamic University of Gaza.

[7] Sulaiman, Ibrahim Suleiman, school departments role in strengthening security in students intellectual, unpublished thesis, Naif Arabic for Security Sciences Riyadh, 2006.

[8] Sanari, RIA Bint Mohamed, ' the role of school management to the prevention of intellectual deviation ', unpublished thesis, Faculty of education, University or villages, Mecca, 2008.

[9] Alshahrani, Bandar bin a bit glad the favorite, depicting a proposal to activate the role of high school intellectual security, unpublished thesis, um Al-Qura University, 2006. 


\section{International Journal of Science and Research (IJSR) \\ ISSN (Online): 2319-7064}

Index Copernicus Value (2016): 79.57 | Impact Factor (2015): 6.391

[10] Al-Otaibi, Saad bin Saleh bin Ryle, ideological security in Islamic education courses in high school, unpublished thesis, um Al-Qura University, College of education, Saudi Arabia, 2009.

[11] Alajmi, Mohamed Hassanein, educational planning and management theory and practice, House of publishing and printing, 1, 2008.

[12] Marwan, Abdul Majeed Ibrahim, foundations of scientific research thesis preparation, blueprints for publishing and distribution, 1, Oman - Jordan, 2000.

[13] Alajmi, Mohamed Hassanein, school management and age requirements, global publishing, Cairo, 2003.

Volume 6 Issue 12, December 2017

www.ijsr.net

Licensed Under Creative Commons Attribution CC BY 